\title{
TTR
}

Traduction, terminologie, re?daction

\section{Yves Gambier and Henrik Gottlieb (eds.). (Multi) Media \\ Translation: Concepts, Practices, and Research, John Benjamins Pulblishing Company, 2001, 298 p.}

\section{Sabine Lauffer}

Volume 14, numéro 2, 2e semestre 2001

Antoine Berman aujourd'hui

Antoine Berman for our time

URI : https://id.erudit.org/iderudit/000578ar

DOI : https://doi.org/10.7202/000578ar

Aller au sommaire du numéro

Éditeur(s)

Association canadienne de traductologie

ISSN

0835-8443 (imprimé)

1708-2188 (numérique)

Découvrir la revue

Citer ce compte rendu

Lauffer, S. (2001). Compte rendu de [Yves Gambier and Henrik Gottlieb (eds.). (Multi) Media Translation: Concepts, Practices, and Research, John Benjamins Publishing Company, 2001, 298 p.] TTR, 14(2), 232-235.

https://doi.org/10.7202/000578ar d'utilisation que vous pouvez consulter en ligne.

https://apropos.erudit.org/fr/usagers/politique-dutilisation/ 
quiconque se préoccupe d'équité linguistique. Livre que je referme sur le pressant désir de lire le Comment à la suite du Pourquoi.

\title{
Claude Tatilon Collège Glendon, Université York
}

\begin{abstract}
Yves Gambier and Henrik Gottlieb (eds.). (Multi) Media Translation: Concepts, Practices, and Research, John Benjamins Publishing Company, 2001, 298 p.
\end{abstract}

(Multi) Media Translation is a collection of twenty-six articles that addresses how the rapid changes in technology and the globalization of communication networks have added new domains to the field of translation and are challenging the translator's role. The contributions are the selected works from two recently organized events: the Misano Seminar on Multimedia \& Translation (September 26-27, 1997); and the Berlin conference on Quality and Standards in Audiovisual Language Transfer (October 15-16, 1998).

The twenty-six articles, together with an introduction and an epilogue, are divided into three sections: "Concepts", "Policies and Practices" and "Empirical Research". Some topics tend to overlap, but each article offers a fascinating look at the various aspects of multimedia translation.

Part One, titled "Concepts", has seven articles in total. This section ponders the relationship between media and multimedia, verbal and multimedia translation, the links between text, images and sounds, the new models of communication, the new elements and parameters of translation for the cinema, video, television, CD-ROM, the Web, etc. Emphasis is placed on the need for Translation Studies to collaborate across many disciplines such as Communication Studies, Media and Film Studies, Cultural Studies, Information Sciences and Computer Sciences. Several papers, notably Patrick Cattrysse's "Multimedia \& Translation: Methodological Considerations" and Aline Remael's "Some Thoughts on the Study of Multimodal and Multimedia Translation", aim to define and conceptualise the commonly employed term multimedia. They examine the role of language and picture, and 
stress the need to think about translation during multimedia production. In his article "Simultaneous Interpreting for Television and Other Media: Translation Doubly Constrained", Sergio Viaggio calls upon his models of verbal communication and mediation and relates them to the constraints, expectations, and developed norms of simultaneous media translation. Domingo Sánchez-Mesa Martínez's article, "Hypertext and Cyberspace: New Challenges to Translation Studies", discusses the practical and theoretical dimensions for translators working with multimedia forms such as virtual reality and hypertext. "Images of Translation" by Gregor Goethals and "Text and Context in Multimedia Translation" by J. Ritter Werner evaluate the relationship between text and images, and how the meaning is presented in diverse mediums. Both authors pull specific examples from the American Bible Society's Multimedia Translation Programme. J. Ritter Werner describes the steps taken by his NewMedia team in translating a sacred text and preparing it for the World Wide Web. Both articles emphasize how the use of electronic media compels us to rethink the whole translation process and our categories and concepts of quality and fidelity. The final article in part one is titled "About Remakes, Dubbing \& Morphing: Some Comments on Visual Transformation Processes and their Relevance for Translation Theory" by Karin Wehn. The author discusses the various non-linguistic modifications that a film or commercial might undergo during translation and adaptation to a target culture.

Part Two, "Policies and Practices", takes a more concrete approach to translation in current-day situations. Comprised of twelve articles, this section deals mainly with film and television translation. The first three articles are "Shooting in English? Myth or Necessity" by Anne Jäckel; "The Position of Foreign Languages in the Flemish Media" by Reine Meylaerts; and "Disentangling Audiovisual Translation into Catalan from the Spanish Media Mesh" by Patrick Zabalbeascoa, Natàlia Izard and Laura Santamaria. They focus on foreign language and English language domination in television. Each article also examines the translation choices and preferred practices in some countries. "Interpreter-Mediated TV Live Interviews" by Bistra Alexieva; "Conference Interpreters on the Air: Live Simultaneous Interpreting on Italian Television" by Gabriele Mack; and "Live Interlingual Subtitling" by Corien den Boer all discuss the strategies, techniques and difficulties associated with live on the air interpreting and subtitling. The standards, procedures, and practices for ensuring 
quality translations and subtitles are the topic of "Translation Quality. An Organizational Viewpoint" by Eivor Gummerus and Catrine Paro; "Quality Down Under" by Felicity Mueller; "Quality Control of Subtitles: Review or Preview?" by Heulwen James; and "Punctuating Subtitles: Typographical Conventions and their Evolution" by Clara Cerón. In her article "Subtitling for Channel 4 Television", Hazel R. Morgan gives a very detailed account of the subtitling process. The final article is by Linda Dewolf. She examines some unique subtitling conditions in her article "Surtitling Opera".

"Empirical Research" is the title of Part Three, and it contains seven systematic analyses of subtitling. Fotios Karamitoglou takes a close look at the practice and reasons behind subtitling children's television programmes in her article "Children's TV programmes in Greece: Conforming to Superior Norms". Jorge Díaz Cintas discusses the correlation between dialogue lists and quality subtitles in his article "Striving for Quality in Subtitling: the Role of a Good Dialogue List". Alexandra Assis Rosa's study titled "Features of Oral and Written Communication in Subtitling" examines the technical and translational choices to be made when subtitling. She pulls specific examples from Portuguese television. Anne Jäckel's case study titled "The Subtitling of La Haine" evaluates the difficulties behind subtitling a film where the plot is deeply rooted in French society. She exposes the language and cultural restraints posed by source to target culture transfer, the social implications that result from the translation choices made, and the reception by the target audience. In "Transfert des références culturelles dans les sous-titres filmiques", Teresa Tomaszkiewicz deals with the difficulties in translating cultural references that are specific to a given society. She provides a variety of possible solutions to overcome these challenges. Henrik Gottlieb's article "Anglicisms and TV Subtitles in an Anglified World" studies the choices translators make in the Danish subtitling of English-language television programmes. He argues that the strong English presence in practically all world languages has strongly influenced target language word choices. The final article in this section is "Incidental ForeignLanguage Acquisition by Children Watching Subtitled Television Programs" by Marijke Van de Poel and Géry d'Ydewalle. The authors present a detailed study with statistics on foreign-language learning through subtitling. 
Translation in the context of multimedia and technology will continue to evolve and take shape. The articles in this book give an excellent overview of this innovative area of study, and open the door to further research.

\title{
Sabine Lauffer Glendon College, York University
}

\begin{abstract}
Anthony Pym, Negotiating the Frontier. Translators and Intercultures in Hispanic History, Manchester, St Jerome Publishing, 2000, 265 p.
\end{abstract}

D'Anthony Pym, à qui nous devons, entre autres, l'ouvrage le plus pertinent qui soit en matière de réflexion sur la méthodologie de l'histoire de la traduction et sur les rapports - rarement abordés entre ces deux disciplines (Method in Translation History, 1998), paraît maintenant un ouvrage qui reprend en les élargissant et en les complétant des articles produits au cours des quinze dernières années par celui à qui, dans le monde de la traductologie, est d'emblée associé le concept d'interculturalité tout comme la mise en avant du sujet traducteur comme agent de coopération.

L'ouvrage « applique » en quelque sorte les quatre principes de base énoncés dans Method in Translation History : primauté de la causalité (pourquoi décide-t-on de traduire, voire de ne pas traduire?), mise en avant du sujet traducteur, rôle central de l'interculturalité (comme espace d'échange de savoirs) et priorité du présent (l'histoire de la traduction permettant d'exposer, d'analyser et de répondre à des questions d'aujourd'hui). Il vise à situer le débat, suivant les propres mots de l'auteur, " beyond the concerns of local colour or narrow historical representation » (p. 1) et nul doute qu'il livre la marchandise, pour user d'une expression d'ordre économique, un ordre qui, comme le titre lui-même l'indique, occupe ici une place non négligeable. Le plan historique est ici mobilisé pour les continuités, mais aussi les ruptures qu'il permet de mettre au jour : il s'agira, dès lors, non pas de dégager un hypothétique système de pensée hispanique sur la traduction (système que fonderait une culture territoriale, nationale), mais d'opérer une coupe transversale dans l'histoire 